NASA Technical Memnorandum 103228

AIAA-90-2551

\title{
Advanced Propulsion for LEO and GEO Platforms
}

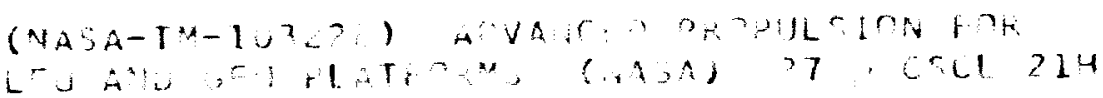

$$
\begin{aligned}
& \text { Noo- } 2773> \\
& \text { Uncl is } \\
& 0,3 / 20 \quad 0302057
\end{aligned}
$$

James S. Sovey

Lewis Research Center

Cleveland, Ohio

and

David J. Pidgeon

George Washington University

Langley Research Center

Hampton, Virginia

Prepared for the

21st International Electric Propulsion Conference cosponsored by the AIAA, DGLR, and JSASS

Orlando, Florida, July 18-20, 1990 

ADVANCEO PROPULSION FOR LEO AND GEO PLATFORMS

\author{
James S. Sovey \\ NASA Lewis Research Center \\ 21000 Brookpark Road, M.S. 500-219 \\ Cleveland, $\mathrm{OH} 44135$ \\ and
}

David J. Pidgeon (a)

George Washington University

NASA Langley Research Center

Hampton, VA 23665-5225

\begin{abstract}
Mission requirements and mass savings applicable to specific low Earth orbit and geostationary Earth orbit platforms using three highly developed propulsion systems are described. Advanced hypergolic bipropellant thrusters and hydrazine arcjets can provide about $11 \%$ additional instrument payload to $14,000 \mathrm{~kg}$ LEO platforms. By using electric propulsion on a $8,000 \mathrm{~kg}$ class GEO platform, mass savings in excess of $15 \%$ of the beginning-of-life platform mass are obtained. Effects of large, advanced technology solar arrays and antennas on platform propulsion requirements are also discussed.
\end{abstract}

\title{
NOMENCLATURE
}

$\begin{array}{ll}\mathrm{I}_{\mathrm{Sp}} & \text { Specific impulse, } \mathrm{s} \\ \mathrm{P}_{\mathrm{e}} & \text { Input power to thruster's power processor } \\ \mathrm{T} & \text { Thrust, } \mathrm{N} \\ \Delta V & \text { Spacecraft velocity change, } \mathrm{m} / \mathrm{s}\end{array}$

\section{INTRODUCTION}

Over the next two decades unmanned, space platforms will be placed in Low Earth Orbit (LEO) and Geostationary Earth Orbit (GEO) to gain a better understanding of Earth science and also provide a test bed for advanced technology systems (refs. 1-10). Mission models include LEO platforms at inclinations from 0 to 90 degrees and GEO platforms. In this paper LEO refers to any orbit with an altitude less than $1000 \mathrm{~km}$. In the near term, free-flying platforms in the 3,000 to $4,000 \mathrm{~kg}$ class will be launched and/or retrieved by the U.S. Space Transportation System (STS) and other launch capabilities. These platforms will be deployed at an altitude of about 300 $\mathrm{km}$. One example is the European Retrievable Carrier (EURECA) platform which will provide about six months mission operation for fifteen experiments (ref. 6 ). The STS will also retrieve the Japanese Space Flyer Unit which will be a test bed for a number of advanced technology experiments (ref. 5). Another program development for LEO platforms is proceeding under the Earth Observing System (EOS) initiative which involves the launch of polar platforms by NASA, ESA, and Japan (refs. 1.4). The 10,000 to $15,000 \mathrm{~kg}$ spacecraft for the Eos missions will be launched by an upgraded Titan IV to an elliptical transfer
(a) Present address: Ford Aerospace
3825 Fabian Way
Palo Alto, CA 94303 
orbit and then will use onboard apogee propulsion to reach a $705 \mathrm{~km}$ circular orbit. Other LEO missions will be accomplished using payloads attached to the Space Station Freedom (SSF) and platforms co-orbiting with the SSF at about $500 \mathrm{~km}$ altitude with an orbit inclination of 28.5 degrees.

Most platforms and communication satellites use either monopropellant hydrazine, hydrazine resistojet, or hypergolic bipropellant thrusters for the on-orbit propulsion operations (refs. 4, 7). The baseline on-board propellant subsystems for the Eos platform are hypergolic bipropellants for apogee propulsion and end-of-mission disposal into the ocean and monopropellant hydrazine systems for on-orbit operations (ref. 4). Figure 1 shows the on-orbit propellant mass fractions for the baseline Eos platform. More than $1800 \mathrm{~kg}$, or $13 \%$ of the beginning-of-life (BOL) platform mass, is propellant (ref 4). In addition, the amount of on-board propellant to be used for orbit acquisition is $935 \mathrm{~kg}$ or about $6 \%$ of the platform transfer orbit mass. Figure 1 also shows that the propulsion mass fractions for a GEO platform and INTELSAT $V$ are significant. Both systems employ resistojets ( $I_{S p} \sim 300 \mathrm{~s}$ ) for North/South (N/S) stationkeeping and monopropellant hydrazine ( $I_{S p} \sim 200$ s) for all the other functions (refs.10-12). Figure 1 indicates that $23 \%$ or $1870 \mathrm{~kg}$ of the baseline GEO platform is propellant (ref. 8). For comparison purposes, the smaller INTELSAT $V$ has a BOL propellant mass fraction of $18 \%$ (refs. 7,10$)$. The INTELSAT $V$ propellant mass fraction is smaller because the design life is $7 \mathrm{yr}$ versus $10 \mathrm{yr}$ for the GEO platform.

Previous work has generally shown the influence of on-board propulsion on overall mission performance of LEO and GEO satellites and characterized emerging high performance propulsion technologies (refs. 11-13). General applicability of on-orbit electric propulsion to SSF co-orbiting platforms and polar platforms has also been analyzed (ref. 14). Electric propulsion options for over thirty LEO free flying spacecraft have been investigated (ref. 13). The $\Delta V$ 's and propellant requirements for LEO transfer, reboost to overcome atmospheric drag, and inclination changes were determined with a sensitivity to life-cycle propellant mass savings. GEO platform servicing and payload delivery missions have been analyzed using chemical and 0.1 to 1 MW electric orbit transfer vehicles (ref. 15).

This paper describes three advanced propulsion system technologies which were applied to large LEO and GEO platforms and were compared to baseline systems which employed monopropellant hydrazine for all on-orbit propulsion and conventional nitrogen tetroxide/monomethyl hydrazine (NTO/MMH) for LEO acquisition and deboost. In all cases, the advanced propulsion system dry mass estimates and thruster $l i f e$ requirements were very conservative and generally were based on state-of-the-art component and subsystem characterizations. The advanced propulsion technologies comprised hypergolic bipropellant devices with high temperature thrust chambers for orbit acquisition and end-of-life (EOL) disposal and hydrazine arcjets or xenon ion thrusters for on-orbit propulsion. Monopropellant hydrazine thrusters provided the remaining orbit maintenance and control functions. The low power arcjets and ion thrusters were not considered for Eos platform orbit acquisition since atmospheric drag exceeds the attainable thrust levels at the perigee altitude $(185 \mathrm{~km})$ of the transfer orbit. Platform servicing and refueling were not considered in this analys is since these complex operations have generally not been considered for near-term polar or GEO platforms. High power orbit transfer to half-GEO and GEO using electric propulsion is beyond the scope of this paper and has been reported elsewhere (refs. 16-18). 


\section{ADVANCED PROPULSION SYSTEMS}

Advanced hypergolic bipropellant (NTO/MMH) thrusters, low-power arcjets, and ion thrusters are being developed in focused technology programs with a view towards near term applications on communication satellites, as well as planetary and LEO spacecraft (refs. 19-23). The chemical and electric propulsion systems can also accommodate platform requirements for boost/deboost and on-orbit propulsion, respectively. The characteristics and technology status of the advanced propulsion systems are described.

\section{Bipropellant Thrusters}

Conventional NTO/MMH bipropellant thrusters are fabricated from columbium, which is coated with silicides for oxidation protection. These thrusters are used on the Space Shuttle orbiter and a wide variety of GEO communication satellites (ref. 11). In many spacecraft, both apogee injection and on-orbit propulsion are performed by the NTO/MMH thrusters. Thrust levels range from $22 \mathrm{~N}$ to hundreds of Newtons at a specific impulse of about 280 to $310 \mathrm{~s}$. Advanced development bipropellant thrusters have thrust chambers fabricated from rhenium coated with iridium by a chemical vapor deposition process (refs. $19,24,25)$. The basic fabrication sequence is illustrated in Fig. 2 . This fabrication method allows operating temperatures to be increased by about 800 $K$, thus eliminating the need for film cooling, which was used to prevent failure of silicide coatings. The resulting improvement in propellant mixing provides an increase in specific impulse of 20 to $30 \mathrm{~s}$. Because the rhenium/iridium system offers an operational capability approaching $2300^{\circ} \mathrm{C}$, trades involving film cooling, performance, and lifetime can be made including operation at lower temperatures to produce greater than a tenfold increase in operating life (ref. 19). Technology demonstrations have been performed using $22 \mathrm{~N}$ and $440 \mathrm{~N}$ thrusters. The $22 \mathrm{~N}$ thrust chamber is capable of operating at temperatures in excess of $2200^{\circ} \mathrm{C}$ with storable propellants for durations in excess of 15 hours (ref. 25 ).

\section{- Hydrazine Arcjet}

A one-kilowatt class hydrazine arcjet system including the arcjet, catalyst bed, power processor and interconnecting power cable has been developed to an engineering model level, and vibration, thermal/vacuum, and electromagnetic compatibility tests have been performed (ref. 26). The arcjet, valve, and gas generator are illustrated in Fig. 3. Mission average specific impulse levels of 450 to over $500 \mathrm{~s}$ have been demonstrated at thrust levels of about $0.2 \mathrm{~N}$. The low power arcjet offers significant specific impulse improvement compared to 180 to $220 \mathrm{~s}$ for the conventional monopropel lant hydrazine thrusters, 280 to $300 \mathrm{~s}$ for hydrazine resistojets, and about $290 \mathrm{~s}$ for a $22 \mathrm{~N} \mathrm{NTO/MMH}$ bipropellant thruster (ref. 11). Extended tests of laboratory class arcjets have been demonstrated over $1000 \mathrm{hr}$ and 500 cycles (ref. 27), which would satisfy the requirements for about 15 years of on-orbit lifetime for $2000 \mathrm{~kg}$ class GEO spacecraft. Post-test component evaluation revealed limited erosion on both the cathode and anode. Thruster and power processor vibration tests and thermal vacuum tests have been successfully undertaken (ref. 26). System level electromagnetic compatibility tests and plume characterization are in progress to assure there will be no impact on spacecraft operations (ref.

28). The General Electric Company has recently baselined the low power arcjet for stationkeeping of American Telephone and Telegraph Company's Telstar IV spacecraft (refs. 21, 29). 
Xenon Ion Thruster

Xenon ion thrusters have reached a high level of maturity and have demonstrated specific impulse levels in the 2500 to $5000 \mathrm{~s}$ range for input powers from 1 to $5 \mathrm{~kW}$ (refs. 21-23, 30-32). The basic ion thruster assembly is shown in Figure 4. Further demonstration of ion thruster performance is not a critical issue, since overall efficiencies of 65 to 80 percent have been readily obtained. Extended tests from 500 to 4000 hours have given confidence that there are no life limiters that would preclude operation of 1 to $5 \mathrm{~kW}$ xenon thrusters for periods up to 5000 hours (refs. $23,30,33,34$ ). In addition to $1.4 \mathrm{~kW}$ thruster performance and life documentation, a breadboard-model power processor and a flight-prototype pressure regulator have been exercised in subsystem tests (ref. 30). A radio frequency ion propulsion system has been qualified for an experiment on the European Retrievable Carrier (EURECA) which will be launched in 1991 or 1992 by the Space Shuttle (ref. 32). In 1992, the Japanese will use xenon ion propulsion as the prime $N / S$ stationkeeping system for the Engineering Test Satellite-VI (ref. 23).

\section{EOS CLASS PLATFORM WITH ADVANCED PROPULSION}

The Earth Observing System (EOS) is a long term, international program to study land, ocean and atmospheric processes (ref. 2). The Eos program is envisioned to comprise at least four platforms; two provided by NASA, one by the European Space Agency, and one by Japan. The propulsion system trades will use Eos-A as the baseline platform system (Table I). Eos-A is a polar orbiting platform and will be launched from the Western Test Range into a 185 $x 705 \mathrm{~km}$ elliptical orbit by a Titan IV. The baseline platform mass in the transfer orbit and the final $705 \mathrm{~km}$ circular orbit will be about $15,000 \mathrm{~kg}$ and $14,000 \mathrm{~kg}$, respectively (ref. 4). Typical instrument payload mass will be about $3500 \mathrm{~kg}$, and the total power available to the platform is $6 \mathrm{~kW}$. The observatory components were designed for 5 yr life, but propellant requirements are set for $7.5 \mathrm{yr}$. No servicing or resupply is planned for Eos-A. At the end-of-life the platform will be safely propelled into the ocean.

Platform propulsion requirements, shown in Table II, are for orbit acquisition, 7.5 year orbit maintenance, backup attitude and momentum control, and safe ocean disposal (ref. 4). The baseline platform was to be transferred into the $705 \mathrm{~km}$ sun-synchronous orbit by a set of three-445 $\mathrm{N}$ hypergolic bipropellant apogee thrusters $\left(I_{S p}=298 \mathrm{~s}\right.$ ); another three-thruster set provides redundancy for orbit acquisition. The mission velocity increment $(\Delta V)$ for orbit acquisition from the $185 \times 705 \mathrm{~km}$ transfer orbit was $164 \mathrm{~m} / \mathrm{s}$. The gravity loss $\Delta V$ penalty associated with finite propulsion times and thrust-to-weight ratios of about 0.01 was assessed. Gravity losses for Eos-A orbit acquisition, for example, have been determined to be less than one percent of the impulsive velocity increment. The analys is was performed using the Program to Optimize Simulated Trajectories (POST) code described in reference 35 .

The in-plane orbit maintenance included drag makeup and eccentricity control whose $\Delta V^{\prime} \mathrm{s}$ were $32 \mathrm{~m} / \mathrm{s}$ and $7 \mathrm{~m} / \mathrm{s}$, respectively and the inclination makeup $\Delta V$ was $36 \mathrm{~m} / \mathrm{s}$ (ref. 4). The baseline Eos-A platform used monopropellant hydrazine thrusters ( $\left.I_{S P}=200 \mathrm{~s}\right)$ for all orbit maintenance functions. Monopropellant hydrazine thrusters $\left(I_{S p}=180 \mathrm{~s}\right)$ were assigned $50 \mathrm{~kg}$ of propellant to 
cover the backup attitude control requirement (ref. 4). The bipropellant thruster system also provided a deboost trajectory for positive re-entry of the platform with a $\Delta V$ of $232 \mathrm{~m} / \mathrm{s}$ (ref. 4). The overall propellant requirements for the baseline system, including $3 \%$ propellant residuals and $10 \%$ margin, were $2105 \mathrm{~kg}$ of bipropellants and $675 \mathrm{~kg}$ of hydrazine for 7.5 years of operation (Table III).

Next, the propellant buciget for the advanced propulsion system was determined using advanced bipropellant thrusters $\left(I_{s p}=323 \mathrm{~s}\right), 700 \mathrm{~W}$ hydrazine arcjets for orbit maintenance, and conventional monopropellant hydrazine thrusters for backup attitude control. The advanced bipropellant thrusters primarily involve an improved thrust chamber, so there should be no significant dry mass penalty for replacement of the conventional thrusters. A set of eight $700 \mathrm{~W}$ arcjets were dedicated to in-plane orbit maintenance and inclination control. The eight arcjets would perform the same orbit maintenance as the eight $2.2 \mathrm{~N}$ monopropellant hydrazine thrusters baselined for Eos-A. Each arcjet burn would involve the operation of two thrusters, configured to minimize unwanted disturbance torques, with a total power of $1400 \mathrm{~W}$ to the two power processors. Seven hundred watt arcjets were chosen to minimize power requirements and still perform routine orbit maintenance in a relatively short time period. In the first advanced propulsion case described in Table III, it was assumed arcjet power would be provided by the Eos-A baseline power system. An average arcjet system burn time of about 35 minutes per day would be required. Arcjet burns might be scheduled during housekeeping periods when some of the major power users are not operational. The average energy demand by the arcjet system was $817 \mathrm{~W}$-hr/day. Burn times and energy requirements were based on the arcjet performance defined in Table II (ref. 36).

The arcjet system elements, which included eight thrusters and eight power processing units (PPU), are described in Table IV. Component masses were obtained from references 26,37 , and 38 . A power processor efficiency of 0.90 was assumed (ref. 26). Dissipated power from the power processors was assumed to be handled by the thermal control system with a specific mass of $40 \mathrm{~kg} / \mathrm{kW}$ (ref. 37). The Interface Module contained a housekeeping converter, controller, wire harness and filters (refs. 38, 39). The total mass of the arcjet system was $96 \mathrm{~kg}$ which included a margin of $30 \%$.

The propellant budget for the advanced propulsion system using Eos-A power system (Table III) is $459 \mathrm{~kg}$ less than the Eos baseline. No dry mass benefit was included when the eight baseline monopropellant hydrazine thrusters were removed and replaced by the arcjet system. After adding the arcjet system (96 $\mathrm{kg}$ ) and reducing the tankage needed for hydrazine by $35 \mathrm{~kg}$, the overall mass savings is $398 \mathrm{~kg}$ (Fig. 5). A 0.064 tankage fraction (the ratio of the mass of propellant and pressurant tanks to the mass of propellant) was assumed based on the Geostationary Operational Environmental Satellite (GOES I) experience (ref. 40). The high performance bipropellant system reduced the baseline propeliant budget by $127 \mathrm{~kg}$, while the arcjet system provided a net savings of $271 \mathrm{~kg}$. Only $239 \mathrm{~kg}$ of hydrazine was required to perform 7.5 years of orbit maintenance using the arcjet system. If it is assumed that four thrusters consume most of the propellant, on average about $60 \mathrm{~kg}$ of hydrazine would be used by each of the four arcjets. This is not a very demanding requirement. For example, the comparable mass throughput of hydrazine required by near term communication satellites, which have two active arcjet systems, is $96 \mathrm{~kg}$ per thruster (ref. 26). The overall mass savings using 
advanced propulsion and the Eos-A baseline power system is about $14 \%$ of the baseline propellant budget and is equivalent to an additional payload contingency of $11 \%$.

In another design scenario, the solar array could be uprated to provide additional power to enable two arcjets to be fired simultaneously and independent of the platform core and payload power demands. In this case, the two arcjet systems would require an additional $1.6 \mathrm{~kW}$ including added wire harness losses and 10\% margin. The solar array specific mass was assumed to be about $29 \mathrm{~kg} / \mathrm{kW}$ plus an additional $30 \%$ mass margin (ref. 8). About $61 \mathrm{~kg}$ of solar array would have to be integrated with the platform, and the overall mass reduction would now be about $337 \mathrm{~kg}$.

\section{GEO PLATFORMS}

This stationkeeping propulsion benefits analysis will examine a single GEO platform generally described in Table I and Figure 6 (refs. 8, 41). The platform would be transferred to GEO by using either perigee/apogee propulsion from a GEO transfer orbit or by direct insertion employing an orbit transfer vehicle. In either case an advanced launch vehicle would be required or platform assembly would be performed in LEO after multiple launches. For this study, the beginning-of-life mass in GEO was 7,000 to $9,000 \mathrm{~kg}$ depending on the type of propulsion, and the payload was fixed at $3840 \mathrm{~kg}$. The platform power system was designed to provide $3.2 \mathrm{~kW}$ to the power bus at the end of the
10 year design life. No on-orbit servicing was considered.

Relatively large passive microwave radiometers (PMR) are mounted on the main truss of this platform (Fig. 6). Bus subsystems and Earth pointing instruments are housed in two 3-meter modules located on the main truss. Power is supplied by two solar array panels, each of which is about $15 \mathrm{~m}^{2}$ (ref. 5). The design is based on the Advanced Photovoltaic Solar Array (APSA), which employs an accordion folded blanket with a specific mass of 14.3 $\mathrm{kg} / \mathrm{kW}$ (refs. 8,42 ). Nickel-Hydrogen batteries were selected for this study. Sizing routines yield $81 \mathrm{~kg}$ battery mass for a $3.2 \mathrm{~kW}$ power supply and a 1.2 hour eclipse period (ref. 8). Table $V$ identifies some of the basic analysis assumptions related to the platform propulsion, power and thermal subsystems.

The GEO platform baseline propulsion system has monopropellant hydrazine thrusters performing all on-orbit propulsion operations. The propulsion analysis will show the benefits of using either hydrazine resistojets, hydrazine arcjets, or xenon ion thrusters to perform $\mathrm{N} / \mathrm{S}$ stationkeeping while $\Delta V^{\prime}$ s associated with $E / W$ stationkeeping, momentum control, some orbit acquisition maneuvers, and EOL boost would be undertaken using either 2.2 or $22 \mathrm{~N}$ monopropellant hydrazine thrusters in all situations. Propulsion requirements are shown in Table VI. The platform consisted of about $30 \mathrm{~m}^{2}$ of solar array and two large passive microwave radiometers with diameters of about 7.5 and $15 \mathrm{~m}$, resulting in an effective platform area-to-mass of approximately $0.06 \mathrm{~m}^{2} / \mathrm{kg}$ (ref. 8). This area-to-mass is sufficiently small so that just as with typical GEO satellites, the $N / S$ stationkeeping $\Delta V$ requirement dominates $E / W$ stationkeeping.

$\mathrm{N} / \mathrm{S}$ stationkeeping thruster performance is shown in Table VII. The nominal specific impulse assumed for the monopropellant hydrazine, resistojet, arcjet, and xenon ion thrusters was $200,290,450$ and $2800 \mathrm{~s}$, respectively. Power to 
each resistojet subsystem was $400 \mathrm{~W}$ (refs, 8, 43), while $1400 \mathrm{~W}$ was supplied to each arcjet and ion thruster subsystem. Input power and performance levels are representative of flight-type or engineering model thrusters (refs. 11 , $12,26,30)$. Trades could also be made using higher power $(\sim 5 \mathrm{~kW})$ hydrazine arcjets and xenon ion thrusters since these devices are currently being developed under NASA's focused technology programs but, at present they have not reached the maturity of the $1.4 \mathrm{~kW}$ systems (refs. 19,30). The number of $1.4 \mathrm{~kW}$ arcjets and ion thrusters to perform stationkeeping is dictated by guidelines associated with maximum burn time per day, as well as thruster lifetime and redundancy. The stationkeeping maneuvers were assumed to be restricted to housekeeping periods of about 90 minutes when some payload instruments would not be operational. This operation mode will result in about $1.6 \mathrm{~kW}$ of payload power available for propulsion (ref. 8). Reducing stationkeeping operations to less than 90 minutes per day also minimizes interaction times of propulsion with platform payloads or experiments. The prime lifetime limiters for the $1.4 \mathrm{~kW}$ arcjet and ion thruster are anticipated to be the hydrazine gas generator and ion optics charge exchange erosion, respectively. The lifetime target for the arcjet was selected to be 1000 to $1500 \mathrm{hr}$ while the ion thruster target was $10,000 \mathrm{hr}$ based on 1990 NASA technology goals. In order to satisfy the maximum burn time guideline and also reduce thruster lifetime requirements two sets of two arcjets (or two sets of four ion thrusters) were selected to share N/S stationkeeping. Table VIII summarizes the power requirements for the baseline platform and the advanced technology versions using arcjets or ion thrusters (ref. 8). An additional $1.0 \mathrm{~kW}$ and $3.8 \mathrm{~kW}$ of power above the baseline system was required for the arcjet and ion thruster systems, respectively. The power system mass for the arcjet system and the ion thruster system was in excess of the baseline system by $30 \mathrm{~kg}$ and $122 \mathrm{~kg}$, respectively.

Next, the on-orbit propulsion system dry mass was estimated. References are cited in Table IX for the mass estimate of each element of the propulsion systems. The ion thruster mass is $12.7 \mathrm{~kg}$ per thruster, and was based on a laboratory model device (ref. 44). To date, no attempt has been made to reduce the mass of the $1.4 \mathrm{~kW}$ xenon ion thruster by using high strength, low mass materials. Gimbal mass was taken to be $30 \%$ of the thruster mass (ref. 44). Ion thruster gimbaling was assumed to insure there were no roll moments produced by uncertainty or movement of the platform center-of-mass. Thrust modulation can maintain spacecraft attitude when yaw torques are produced (refs. 45). Except for the ion propulsion system, each of the other $N / S$ stationkeeping options has two thrusters on both the North and South faces of the platform, with two redundant thrusters on each face. The ion system has four thrusters on each of the North and South faces and two redundant thrusters on each face. Electric propulsion hardware redundancy and power utilization on communication satellites is discussed in reference 22 . Thermal control mass for the propulsion systems was taken to be $40 \mathrm{~kg}$ per kilowatt of power dissipated from the power processor (ref. 37). Tankage fractions of 0.064 and 0.15 were assumed for hydrazine and xenon, respectively (refs. 30 , 40). Tank structure was taken to be $4 \%$ of the sum of the propellant and tankage masses (ref. 39). Including tankage, the arcjet system had the lowest dry mass of $296 \mathrm{~kg}$. followed by resistojet, monopropellant hydrazine, and ion systems with dry masses of 348,376 , and $610 \mathrm{~kg}$, respectively. Further reductions in all system dry masses might be possible by mass optimization during a flight development program. 
Table $X$ and Fig. 7 show the BOL GEO platform mass summary. The arcjet and ion system propellant masses are $57 \%$ and $25 \%$ of the hydrazine required by the baseline system which employed monopropellant hydrazine thrusters for N/S stationkeeping. After factoring in the propulsion dry masses and power system masses, the GEO platforms with the monopropellant hydrazine, resistojet, arcjet, and ion thruster options had total masses of 8734, 7973, 7430, and $7162 \mathrm{~kg}$, respectively. The resulting mass benefit using the arcjet system was about $1304 \mathrm{~kg}$ and the ion system produced a mass benefit of $1572 \mathrm{~kg}$. The electric propulsion systems for platform N/S stationkeeping can provide mass savings equivalent to $15 \%$ to $18 \%$ of the baseline BOL platform mass.

The N/S stationkeeping propellant requirements for the ten year GEO platform imply each of the four active arcjets must handle a hydrazine throughput of about $176 \mathrm{~kg}$, which implies a total operating time of about 1080 hours.

Present generation arcjets are required to process about $96 \mathrm{~kg}$ of hydrazine over 607 hours for communication spacecraft applications (ref. 20). Thus, the $1.4 \mathrm{~kW}$ arcjets and the hydrazine gas generators used for platform stationkeeping will have a longer life requirement than needed on smaller GE0 spacecraft, but $1000 \mathrm{hr}$ thruster life has been readily demonstrated in ground tests (ref. 27). On average each of the eight ion thrusters would be required to process about $14 \mathrm{~kg}$ of xenon over the ten year mission life. Ion thruster operation time would only be about $1750 \mathrm{hr}$. Xenon ion thrusters, with $0.023 \mathrm{~N}$ thrust levels, will perform N/S stationkeeping on the Japanese Engineering Test Satellite (ETS VI), starting in 1992 (ref. 46). The ETS-VI ion thrusters deliver about one-third the thrust of the $25 \mathrm{~cm}$ diameter thruster specified for the platform stationkeeping. An ETS-VI thruster will process about $20 \mathrm{~kg}$ of xenon over its 6500 hour lifetime. The GEO platform ion thruster lifetime requirements are less demanding than those of ETS-VI since eight higher power ion thrusters are involved in the stationkeeping process.

Arcjets and ion thrusters are presently being developed for near term applications on $2000 \mathrm{~kg}$ class GEO spacecraft. By using electric propulsion on $8000 \mathrm{~kg}$ GEO platforms, mass savings equivalent to $15 \%$ to $18 \%$ of baseline platform mass can be obtained with modest lifetime requirements of $1080 \mathrm{hr}$ and $1750 \mathrm{hr}$ for hydrazine arcjets and xenon ion thrusters, respectively. Major issues concerning implementation of electric propulsion, such as system integration, power utilization, flight qualification, and particle and field interactions are summarized in references 22,26 .

\section{ADVANCED GEO PLATFORM REQUIREMENTS}

Advanced platforms will employ larger antennas and solar arrays, and thus the area-to-mass of platforms may increase dramatically. The large systems will increase the East/West drift in GEO orbit. The drift is caused by solar radiation pressure and disturbances due to the Earth's triaxiality (ref. 8 ). Figure 8 shows the yearly $E / W$ stationkeeping $\Delta V$ versus area-to-mass. $N / S$ stationkeeping is generally unaffected. Daily corrections of the $E / W$ disturbance have generally not been done because autonomous control systems have not been implemented. Such control systems may produce significant benefits as platform area-to-mass approaches about $0.3 \mathrm{~m}^{2} / \mathrm{kg}$. Figure 8 also shows the sensitivity of $E / W \triangle V$ to triaxiality disturbances, which are a function of platform longitudinal position. 
The baseline GEO platform had an $E / W$ stationkeeping $\Delta V$ requirement of about $5.3 \mathrm{~m} / \mathrm{s} / \mathrm{yr}$ and a mean area-to-mass ratio of $0.06 \mathrm{~m}^{2} / \mathrm{kg}$. If, for example, a platform included a $40 \mathrm{~m}$ diameter passive microwave radiometer (PMR), the area-to-mass ratio would increase by a factor of 4.6 . The resulting $E / W$ stationkeeping $\Delta V, 38 \mathrm{~m} / \mathrm{s} / \mathrm{yr}$, is nearly comparable to the $\mathrm{N} / \mathrm{S}$ stationkeeping requirement.

Figure 9 shows how platform propellant mass varies as a function of BOL platform mass with area-to-mass as a parameter. Either resistojets ( $I_{s p}=$ $300 \mathrm{~s}$ ) or ion thrusters ( $I_{s p}=2500 \mathrm{~s}$ ) perform the stationkeeping maneuvers which dominate all propulsion requirements. A $7000 \mathrm{~kg}$ platform's propellant budget, using resistojet propulsion, would be increased by approximately 700 $\mathrm{kg}$ to $1940 \mathrm{~kg}$ if the mean platform area-to-mass was increased from 0.06 to $0.28 \mathrm{~m}^{2} / \mathrm{kg}$. By using ion propulsion, the total propellant mass would only be 200 to $300 \mathrm{~kg}$. As platform systems advance to larger solar arrays and antennas, propeliant mass fractions in excess of $30 \%$ of BOL platform mass may be required using conventional propulsion systems. Ion propulsion systems, for example, could reduce the propellant mass fraction of such platforms to less than $5 \%$ of BOL platform mass.

\section{CONCLUSIONS}

Mission requirements and mass savings applicable to specific LEO and GEO platforms are described using three highly developed propulsion systems. Advanced Ir/Re bipropellant thrusters performed the apogee motor function, while hydrazine arcjets or xenon ion thrusters were used for $N / S$ stationkeeping. When advanced bipropellants and arcjets were considered for $14,000 \mathrm{~kg}$ platforms, similar to EOS-A, mass savings which were equivalent to $14 \%$ of the baseline propellant budget or $11 \%$ of the baseline payload were obtained. Arcjet propellant throughput and total impulse requirements were less demanding than those pertaining to near term communication satellites. When electric propulsion was considered for N/S stationkeeping of 8 MT class GEO platforms, the arcjet and ion system propellant masses were only $51 \%$ and $25 \%$ of the hydrazine required by the baseline system which employed monopropellant hydrazine thrusters. The electric propulsion systems provided overall mass savings of 1304 to $1572 \mathrm{~kg}$, which are equivalent to $15 \%$ to $18 \%$ of the BOL platform mass. Each of the four $1.4 \mathrm{~kW}$ arcjet systems used for platform stationkeeping would be required to operate for $1080 \mathrm{hr}$. Which is about 470 hours longer than required for near term communication satellites. However, routine operation of arcjets has been experienced during $1000 \mathrm{hr}$ design verification tests. The lifetime requirement for each of eight ion thrusters was about $1750 \mathrm{hr}$. which is a factor of three lower than that required by systems to be flown in 1992 by the Japanese ETS VI spacecraft. Results of the GEO platform study should be considered quite conservative because of the use of state-of-the-art propulsion technology. Ongoing programs are developing higher power ( 3 to $5 \mathrm{~kW}$ ) arcjet and ion thrusters which would reduce the number of thrusters required for platform stationkeeping.

As platforms advance to larger solar arrays and antennas, the $E / W$ stationkeeping requirement may approach the magnitude of $N / S$ stationkeeping. propellant mass fractions in excess of $30 \%$ of beginning-of-life (BOL) spacecraft mass may be required using conventional propulsion. If ion 
propulsion systems were used for both maneuvers, for example, the propellant mass fraction could be reduced to less than $5 \%$ of BOL platform mass. The leverage electric propulsion exerts on platform systems increases dramatically from Eos class LEO platforms to GEO platforms with relatively large area-to-mass ratios.

\section{ACKNOWLEDGEMENT}

The authors wish to acknowledge the assistance of $\mathrm{Mr}$. Stephen $\mathrm{W}$. Alexander (NASA Lewis Research Center) in the analysis of the $\triangle V$ penalty associated with finite propulsion times. 


\section{REFERENCES}

1. Johnston, G. I. and Hudson, W. R., "Technologies for Monitoring Global Change," AIAA Paper No. 89-0254, January 1989.

2. Scolese, C. J. and Scholz, L. C., "Eos Mission Design Utilizing the Space Station Platforms," AIAA Paper No. 89-0252, January 1989.

3. Snyder, R. E. and Bilardo, V. J., "Space Station Freedom as an Earth Observing Platform," AIAA Paper No. 89 - 0251, January 1989.

4. Anon, Earth Observing System - A System Description, Non-Advocate Review, General Electric Company, June 1989.

5. Kuriki, K. and Obara, H., "An Energetics Experiment on a Space Platform," Space Power, Vol. 7, No. 1, 1988, pp. 75-89.

6. Bassner, H., Berg, H. P., Groh, K. H. and Loeb, H. W., "Recent Developments of the North-South Stationkeeping Engines of the RIT-Family," IAF paper No. 89-273, October 1989.

7. Podraczky, E. and Pelton, J. N., "The Intelsat Global Satellite System," Progress in Astronautics and Aeronautics, Vol. 93, American Institute of Aeronautics and Astronautics, New York, 1984, pp. 113-126.

8. Pidgeon, D. J., "A Subsystem Design Study of an Earth Sciences Geostationary Platform, "Thesis, The George Washington University, Washington, DC, July 1989.

9. Anon, "Geostationary Platform Bus Study for Earth Observational Sciences," Final Report Contract NAS8-36104, September 1987.

10. Agrawa 1, B. N., "Design of Geosynchronous Spacecraft," Prentice Hall, Englewood Cliffs, NJ, 1987.

11. Sackheim, R. L. and Howe 11, G. W., "Trends in Propulsion Systems for Geosynchronous Satellites," 14th International Symposium on Space Technology and Science, Tokyo, Japan, May 1984.

12. McKevitt, F. X., "Design and Development Approach for the Augmented Catalytic Thruster (ACT)," AIAA Paper No. 83-1255, June 1983.

13. Palaszewski, B. A., "Advanced Propulsion for Polar-Orbiting and Co-orbiting Free Flyers," AIAA Paper No. 1564, 1986.

14. Martin, A. R. and Cresdee, M. T., "The Use of Electric Propulsion on Low Earth Orbit Spacecraft, "Journal of the British Interplanetary Society, Vo1. $41,1988, \mathrm{pp} .175-182$.

15. Palaszewski, B. A., "Geosynchronous Earth Orbit Base Propulsion: Electric Propuision Options," AIAA Paper No. 87-0990, May 1987. 
16. Herme 1, J., Meese, R. H., Rogers, W. P., Kusheda, R. 0., Beattie, J. R. and Hyman, J., "Modular, Ion-Propelled, Orbit Transfer Vehicle," J. of Spacecraft and Rockets, Vol. 25, No. 5, Oct. 1988, pp. 368-374.

17. Sponable, J. M. and Penn, J. P., "Electric Propulsion for Orbit Transfer: A Case Study," J. of Propulsion and Power, Vol. 5, No. 4, July-August, 1989, pp. 445-451.

18. Jones, R. M., "Comparison of Potential Electric Propulsion Systems for Orbit Transfer," J. of Spacecraft and Rockets, Vol. 21, Jan.-Feb. 1984, pp. 88-95.

19. Stone, J. R., and Bennett, G. L., "The NASA Low Thrust Propulsion Program," AIAA Paper 89-2492, July 1989.

20. Knowles, S. C., Smith. W. W., Chun, S. I., and Feconda, R. J., "Low Power Arcjets: A System Description for Near-Term Application," 1989 JANNAF Meeting, Cleveland, Ohio, May 1989.

21. Beattie, J. R. and Penn, J. P., "Electric Propulsion - A National Capability," AIAA Paper No. 89-2490, July 1989.

22. Schreib, R., "Readiness Appraisal: Ion Propulsion for Communication Satellites," AIAA Paper No. 88-0777, March 1988.

23. Kuriki, K. and Nakamura, Y., "Electric Propulsion Projects and Researches in Japan," Proceedings of the 20th International Electric Propulsion Conference, pp 26-36, October 1988.

24. Harding, J. T., Kazaroff, J. M., and Appe 1, M. A., "Iridium-Coated Rhenium Thrusters by CVD," NASA TM-101309, September 1988.

25. Wooten, J. R. and Lansaw, P. T., "The Enabling Technology for Long-Life, High Performance On-Orbit and Orbit Transfer Propulsion Systems: High Temperature, Oxidation Resistant Thrust Chambers," 1989 JANNAF Propulsion Meeting, Cleveland, $\mathrm{OH}$, May 1989.

26. Knowles, S. C. and Yano, S. E., "Design, Testing and Integration of a Flight-Ready Hydrazine Arcjet System," AIAA Paper No. 89-2720, July 1989.

27. Curran, F. M. and Haag, T. W., "An Extended Life and Performance Test of a Low-Power Arcjet," AIAA Paper No. 88-3106, July 1988 (NASA TM-100942).

28. Carney, L. M., "Evaluation of the Communications Impact of a Low-Power Arcjet Thruster," AIAA Paper No. 88-3105, July 1988.

29. Marcus, D. J., "AT\&T is First to Buy Advanced Thruster on GE Satellites," Space News, Jan. 15-21, 1990.

30. Beattie, J. R., Mattosian, J. N., and Robson, R. R., "Status of Xenon Ion Propulsion Technology," AIAA Paper 87-1003, 1987. 
31. Fearn, D. G., Martin, A. R., and Smith, P., "Ion Propulsion Research and Development in the UK," 40th Congress of the INternational Astronautical Federation No. 89-274, Malaga, Spain, October 1989.

32. Bassner, H. F., Berg, H-P., and Kukies, R., "Radiofrequency Ion Propulsion Appiication to Commercial Satelites," AIAA Paper No. 89-2276. July 1989 .

33. Rawlin, V. K., "Internal Erosion Rates of a 10kW Xenon Ion Thruster," AIAA Paper No. 88-2912, JuTy 1988.

34. Patterson, M. J. and Verhey, T. J., "5kW Xenon Ion Thruster Lifetest," AIAA Paper 90-254:, July 1990.

35. Braver, G. L., Cornick, D. E., 01son, D.W., Petersen, F. M., and Stevenson, R., "Program to Optimize Simulated Trajectories (POST)," NASA CR 87-583, September 1987.

36. Curran, F. and Sarmiento, C., "Low Power Arcjet Performance Characterization," AIAA Paper No. 90-2578, July 1990.

37. Anon., "NASA Space Systems Technology Mode1," NASA TM-88176, Vol. 2 Data Base, Technology Analysis, June 1985.

38. Patterson, J. J. and Curran, F. M., "Electric Propulsion Options for 10kW Class Earth Space Missions," NASA TM-102337, May 1989.

39. Byers, D. C., Terilan, F. F., and Myers, I. T., "Primary Electric Propulsion for Future Space Missions," NASA TM-79141, May 1979.

40. Anon., Quarterly Mass Management Summary for GOES I, Ford Aerospace Corporation, January 1990.

41. Anon., "Geostationary Platform Bus Study for Earth Observational Sciences," Final Report, Contract NAS8-36104, September 1987.

42. Kurland, R. and Stella, P. M., "Status of Advanced Solar Array Program," Proceedings of the 23rd Intersociety Energy Conversion Conference, Vol. 2. Denver, CO, Aujust 1988, pp. 91-95.

43. Feconda, R. T. and Weizman, J. I., "Satellite Reaction Control Subsystem with Augmented Catalytic Thrusters," AIAA Paper 84-1235, June 1984.

44. Brophy, J. R. and Aston, G., "A Detailed Model of Ion Propulsion Systems," AIAA Paper 89-2268, July 1989.

45. Anon., "Engineering Support for Pre-Launch, Launch, Post-Launch, and Mission Operation Phases of the Ion Auxiliary Propulsion System Flight Test," Monthly Report on NAS3-24862. Hughes Aircraft, March 1990.

46. Shimada, S., Takegahara, H., Gotoh, Y., Satoh, K., and Kajiwara, K., "Ion Engine System Development of ETS-VI," AIAA Paper 89-2267, July 1989. 
TABLE I - PLATFORM CHARACTERISTICS

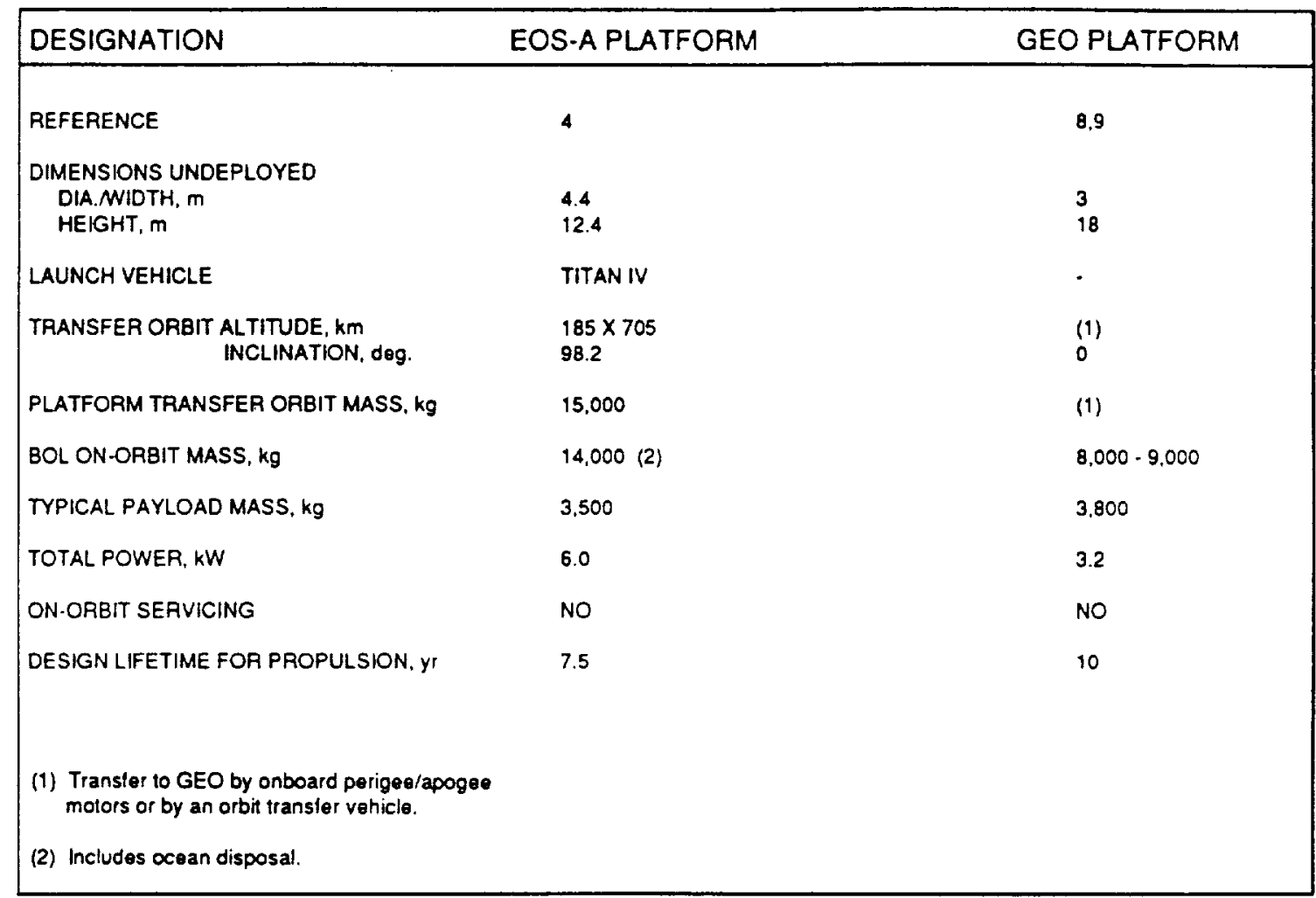

TABLE II - EOS CLASS PLATFORM PROPULSION SYSTEMS

\begin{tabular}{|c|c|c|c|}
\hline MANEUVER & $\begin{array}{l}\text { DELTA-V } \\
\text { REQUIREMENT, } \\
\mathrm{m} / \mathrm{s},(\text { ref. } 4 \text { ) }\end{array}$ & $\begin{array}{l}\text { EOS-A } \\
\text { BASELINE, } \\
\text { (ref. 4) }\end{array}$ & $\begin{array}{l}\text { ADVANCED } \\
\text { PROPULSION }\end{array}$ \\
\hline ORBIT ACOUISITION & 164 & $\begin{array}{l}\text { NTOMMMH } \\
\text { SILICIDE-COATED NB CHAMBER } \\
K S P=298 \mathrm{~s} \\
T=445 \mathrm{~N}\end{array}$ & $\begin{array}{l}\text { NTO/MMH } \\
\text { IR-LINED RE CHAMBER } \\
\text { Isp }=323 \mathrm{~s} \\
T=445 \mathrm{~N}\end{array}$ \\
\hline $\begin{array}{l}\text { ORBIT MAINTENANCE } \\
\text {-DRAG MAKEUP } \\
\text {-ECCENTRICITY CONTROL } \\
\text {-INCLINATION CONTROL }\end{array}$ & $\begin{array}{l}32 \\
7 \\
35\end{array}$ & $\begin{array}{l}\mathrm{N} 2 \mathrm{H}_{4} \\
\operatorname{lsp}=200 \mathrm{~s} \\
\mathrm{~T}=2.2 \mathrm{~N}\end{array}$ & $\begin{array}{l}\text { N2H4 ARCJET } \\
\text { Pe }=700 \mathrm{~W} \\
\text { lsp }=450 \mathrm{~s} \\
T=0.091 \mathrm{~N}\end{array}$ \\
\hline ATTITUDE CONTROL & & $\begin{array}{l}\mathrm{N} 2 \mathrm{H} 4 \\
\mathrm{lsp}=180 \mathrm{~s} \\
T=22 \mathrm{~N}\end{array}$ & $\begin{array}{l}\mathrm{N} 2 \mathrm{H} 4 \\
\operatorname{lsp}=180 \mathrm{~s} \\
T=22 \mathrm{~N}\end{array}$ \\
\hline DISPOSAL OF PLATFORM & 232 & ........SAME AS ORBT ACOUI & 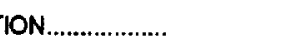 \\
\hline
\end{tabular}




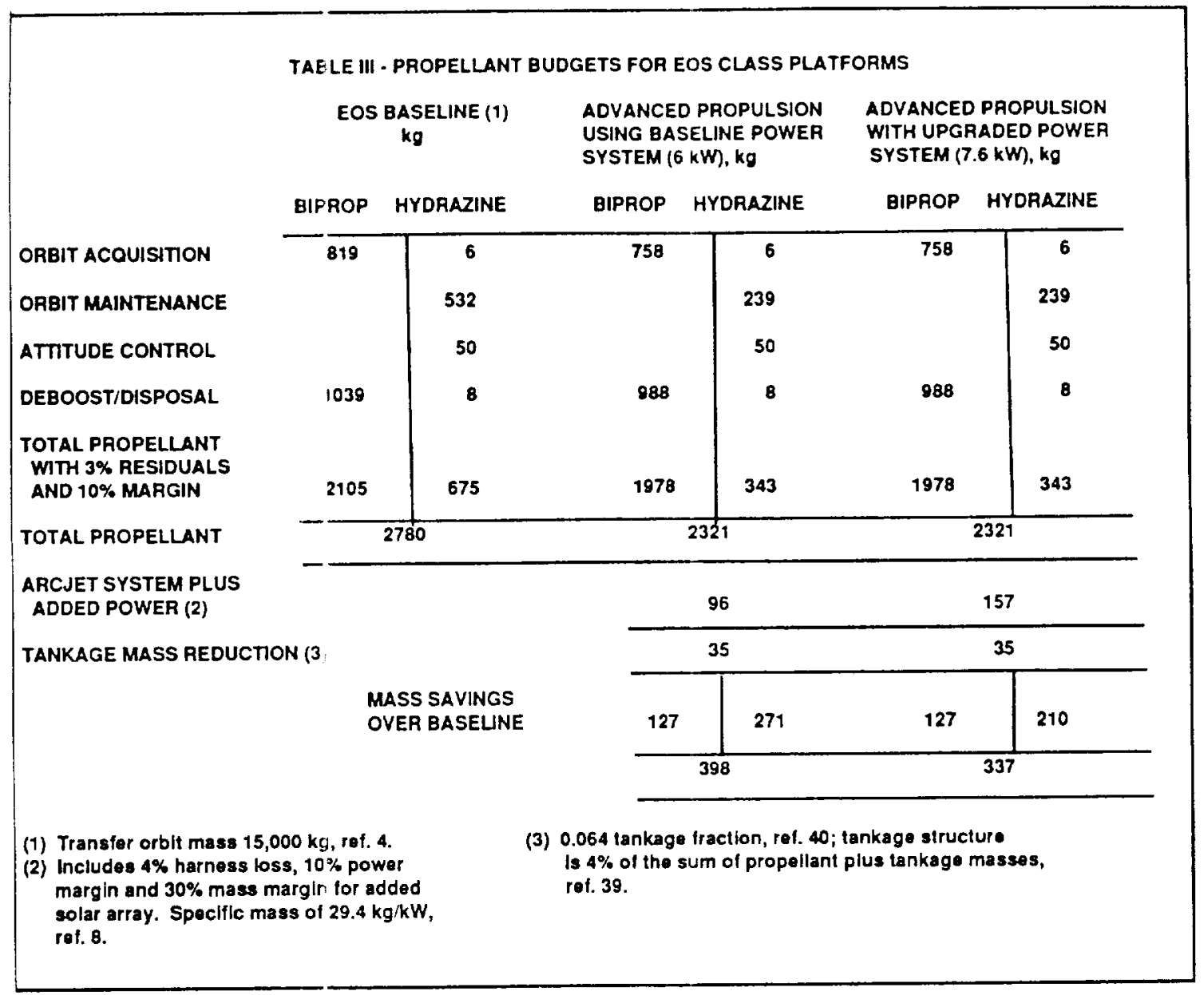

\section{TABLE IV - ARCJET PROPULSION SYSTEM MASS}

$\begin{array}{lc}8 \text { THRIJSTERS (1) } & 9 \mathrm{~kg} \\ 8 \text { POWER PROCESSORS (700 W each) (1) } & 36 \\ \text { THEMMAL CONTROL (2) } & 6 \\ \text { THRUSTER STRUCTURE (3) } & 3 \\ \text { INTERFACE MODULE (3) } & 20 \\ \text { 30\% MARGIN } & 22 \\ \text { TOTAL MASS } & 96 \mathrm{~kg}\end{array}$

(1) Scaled from ret. 26

Power to PPU/thruster: $700 \mathrm{~W}$.

(2) Based on $40 \mathrm{~kg} / \mathrm{kW}$ of dlsslpated

power, ref. 37

(3) Estlmated from 5 to $10 \mathrm{~kW}$ oy stems,

rol. 38. 
TABLE V - GEO PLATFORM SUBSYSTEM DEFINITION AND ANALYSIS ASSUMPTIONS

- N/S STATIONKEEPING PERFORMED BY ONE OF FOUR PROPULSION OPTIONS

- EW STATIONKEEPING MOMENTUM CONTROL ORBIT TRIMMING, AND END-OF-LIFE MANEUVER PERFORMED BY $2.2 \mathrm{~N}$ AND $22 \mathrm{~N}$ MONOPROPELLANT HYDRAZINE THRUSTERS

- 30\% MARGINS INCLUDED IN POWER ANO PROPULSION SYSTEM DRY MASSES

- PROPELLANT MASS INCLUDES 3\% RESIDUALS AND 10\% MARGIN

- 50 MICROMETER SHLICON SOLAR CELLS (14.3 kgkW), 50 VDC POWER SYSTEM, ref. 41

- MAGNETIC BEARING REACTION WHEEL ATTITUDE CONTROL SYSTEM

- PASSIVE THERMAL CONTROL SYSTEM (40 kgkW), rol. 37

TABLE VI - PROPULSION SYSTEM REQUIREMENTS FOR A 10 YEAR PLATFORM

\begin{tabular}{|c|c|c|}
\hline PROPULSION FUNCTION & $\begin{array}{l}\text { DELTA-V REQUIREMENT, } \\
(\mathrm{m} / \mathrm{s}), \text { ref. } 8\end{array}$ & THRUSTER SYSTEM \\
\hline N/S STATIONKEEPING & 440 & FOUR OPTIONS \\
\hline EW STATLONKEEPING & 53 & \\
\hline $\begin{array}{l}\text { MOMENTUM CONTAOL } \\
\text { ROLL } \\
\text { PITCH } \\
\text { YAW }\end{array}$ & $\begin{array}{l}1.4 \\
13.1 \\
0.1\end{array}$ & $\begin{array}{l}\text { MONOPROPELANT } \\
\text { HYDRAZINE }\end{array}$ \\
\hline OABIT ACOUISITION & 45 & \\
\hline EOL ORBIT $300 \mathrm{~km}$ BOOST & 13 & \\
\hline
\end{tabular}




\begin{tabular}{|lcccc|}
\hline \multicolumn{5}{c}{ TABLE VII - TYPICAL THRUSTER CHARACTERISTICS } \\
\hline PROPULSION SYSTEM & THRUST, N & SPECIFC IMPULSE, & POWER, $W$ & REFERENCE \\
\hline MONOPROPELLNT HYORAZNE & 22,22 & 200 & - & 11 \\
HYDRAZINE RESISTOJET & 0.23 & 200 & 400 & 11,12 \\
HYDRAZINE ARCJET & 0.20 & 450 & 1400 & 26 \\
XENON ION THRUSTER & 0.061 & 2800 & 1400 & 30 \\
\end{tabular}

TABLE VIII - POWER SYSTEM MASS SUMMARY

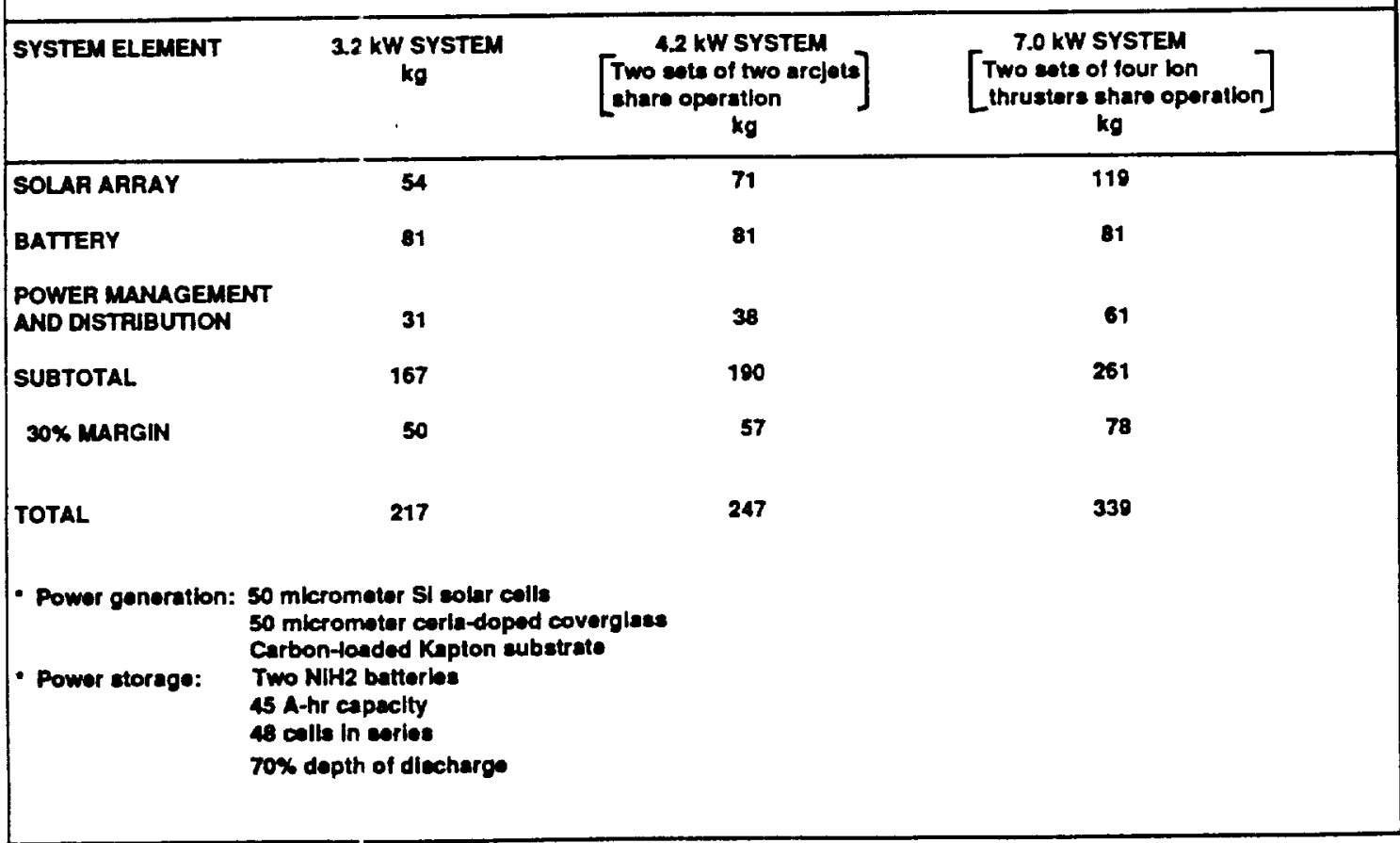


TABLE IX - ON-ORBIT PROPULSION SYSTEM DRY MASS FOR A GEO PLATFOAM

\begin{tabular}{|c|c|c|c|c|c|c|c|c|}
\hline \multirow{2}{*}{$\begin{array}{c}\text { N/S STATIONKEEPING } \\
\text { OPTION } \longrightarrow \\
\text { SUBASSEMBLY }\end{array}$} & \multicolumn{2}{|c|}{$\begin{array}{l}\text { MONOPROPELLANT } \\
\text { HYDRAZINE }\end{array}$} & \multicolumn{2}{|c|}{$\begin{array}{l}\text { HYDRAZINE } \\
\text { RESISTOJET }\end{array}$} & \multicolumn{2}{|c|}{$\begin{array}{l}\text { HYDRAZINE } \\
\text { ARCJET }\end{array}$} & \multicolumn{2}{|c|}{$\begin{array}{l}\text { XENON } \\
\text { ION THRUSTER }\end{array}$} \\
\hline & QUANTITY & MASS, kg & atr & MASS, kg & OTY & MASS, kg & OTY & MASS, kg \\
\hline $\begin{array}{l}\text { NS STATONKEEPING } \\
\text { THRUSTERSICIMEALS }\end{array}$ & 8 & $3(1,8)$ & 8 & $7(1,2)$ & 8 & $12(1,3)$ & 12 & $198(5)$ \\
\hline POWER PROCESSORS & & & 8 & $20(4)$ & 8 & 37 (3) & 12 & $120(5)$ \\
\hline THERMAL CONTROL (6) & & & & 13 & & 11 & & 23 \\
\hline THRUSTER STRUCTUAE ( $)$ & & 1 & & 2 & & 3 & & 13 \\
\hline \multicolumn{9}{|l|}{ MONOPROPELLANT } \\
\hline N2H4 THRUSTERS (B) & 16 & 5 & 16 & $\mathbf{5}$ & 16 & 5 & 16 & $\mathbf{5}$ \\
\hline \multicolumn{9}{|l|}{ WTERFACE MODULE } \\
\hline \multicolumn{9}{|l|}{ AND PROPELLANT } \\
\hline FEED SYSTEM ( 7 ) & & $\mathbf{5}$ & & 16 & & 20 & & 25 \\
\hline SUBTOTAL & & 14 & & 72 & & 88 & & 384 \\
\hline \multicolumn{9}{|l|}{ TANKAGE INCLUDING } \\
\hline STRUCTURE (9) & & 275 & & 196 & & 140 & $\mathrm{~N}_{2} \mathrm{H}_{4}$ & 54 \\
\hline MARGIN (30\%) & & 87 & & 80 & & 68 & & 141 \\
\hline TOTAL DAY MASS & & 376 & & 348 & & 296 & & 610 \\
\hline
\end{tabular}
(1) No gimbal
(2) rol. 12
(3) ret. 26
(4) rets. 8,13
(5) rota 30,44 . Cimbal mases = $30 \%$ of thruster mase.
(6) Asaume $40 \mathrm{~kg} / \mathrm{kW}$ of dleslpated power, rot. 37
(7) Estimates from 5 to $10 \mathrm{~kW}$ sysioma, ret. 38
(8) ref. 8
(9) Hydrazine tankage frection $=0.064$, ref. 40
Xonon tankage fraetion $=0.15$, rot. 30
Tankege structure fraction $=0.04$ of the sum of propollant plus tankage masese, ret. 30 
TABLE X - GEO PLATFOAM MASS SUMMARY (KG)

\begin{tabular}{|c|c|c|c|c|}
\hline $\begin{array}{l}\text { N/S STATIONKEEPING } \\
\text { SYSTEM } \\
\text { SUBSYSTEM }\end{array}$ & $\begin{array}{l}\text { BASELINE } \\
\text { MONOPROPELLANT } \\
\text { HYDRAZINE (1) }\end{array}$ & $\begin{array}{l}\text { HYDRAZINE } \\
\text { RESISTOJET }\end{array}$ & $\begin{array}{l}\text { HYDRAZINE } \\
\text { ARCJET }\end{array}$ & $\begin{array}{l}\text { XENON ION } \\
\text { THRUSTER }\end{array}$ \\
\hline $\begin{array}{l}\text { GNEC, THERMAL(NON } \\
\text { PROPULSION), DMSTTC, } \\
\text { CE, STRUCTURE (2) }\end{array}$ & 1746 & 1746 & 1746 & 1746 \\
\hline PAYLOAD & 3836 & 3836 & 3836 & 3836 \\
\hline POWER & 217 & 217 & 247 & 339 \\
\hline $\begin{array}{l}\text { PROPULSION } \\
\text { 'DRY MASS }\end{array}$ & 376 & 348 & 206 & 610 \\
\hline $\begin{array}{l}\text {-PROPELLANT (3) } \\
\text {-HYDRAZNE } \\
\text {-XENON }\end{array}$ & 2559 & 1826 & 1305 & $\begin{array}{l}505 \\
126\end{array}$ \\
\hline $\begin{array}{l}\text { BOL PLATFORM MASS } \\
\text { IN GEO, } \mathrm{kg}\end{array}$ & 8734 & 7973 & 7430 & 7162 \\
\hline $\begin{array}{l}\text { MASS SAVINGS } \\
\text { OVER BASEUNE, kg }\end{array}$ & $\cdot$ & 761 & 1304 & 1572 \\
\hline
\end{tabular}

(1) ret. 8

(2) GNEC: Guldance, Navigatlon and Control

DMSTTC: Data Management SyatemTelemetry, Tracking and Command

CE: Control Electronico

(3) Includes $3 \%$ residuals and $10 \%$ margin. 


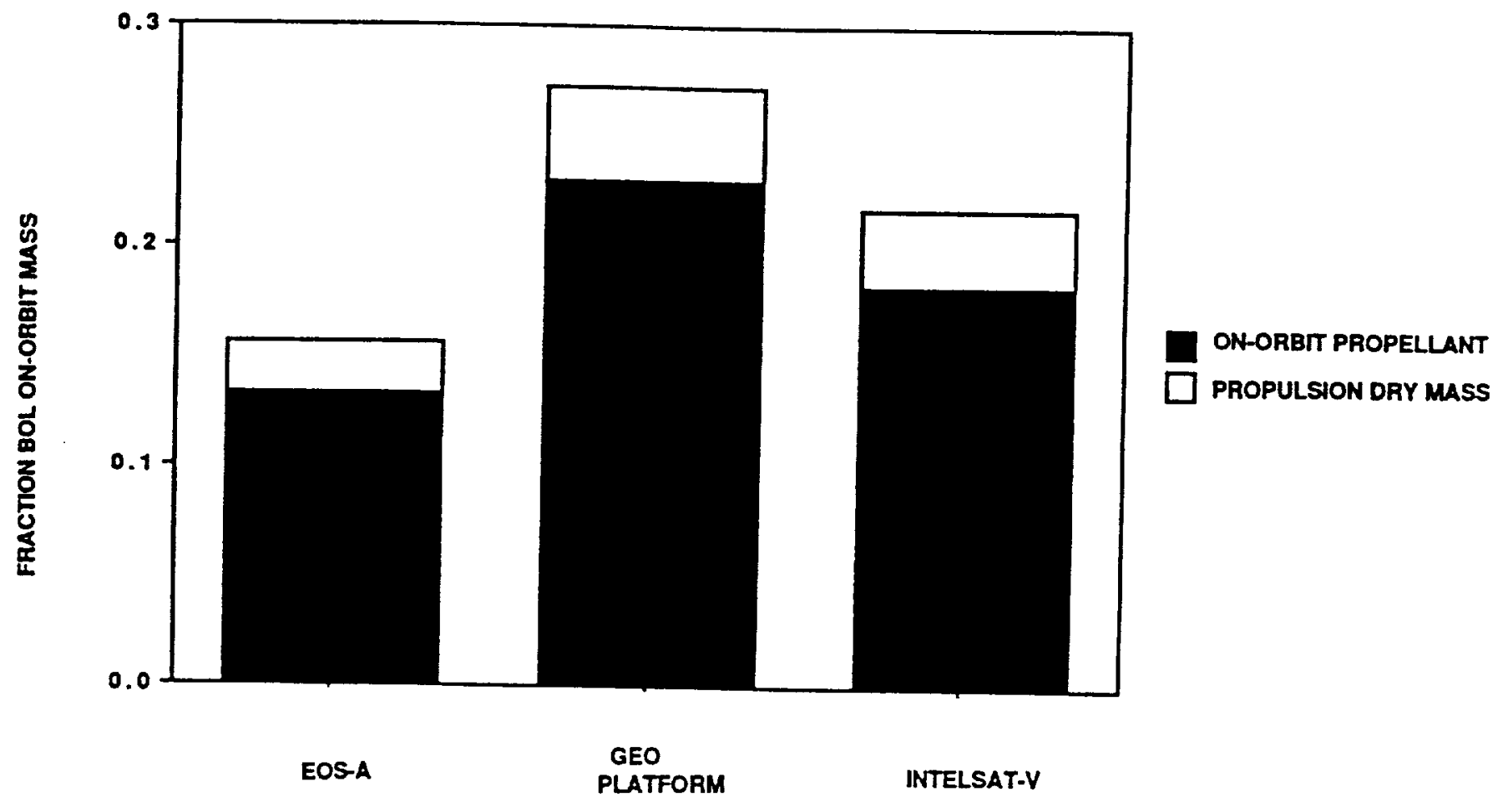

\begin{tabular}{|l|l|l|l|}
\hline \multicolumn{1}{|c|}{ SPACECRAFT } & \multicolumn{1}{|c|}{ EOS-A } & \multicolumn{1}{c|}{ GEO PLATFORM } & \multicolumn{1}{c|}{ INTELSAT-V } \\
\hline ALTIUDE, $\mathrm{km}$ & 705 & 35,800 & 35,800 \\
\hline UFE, $\mathrm{YT}$ & $5^{\circ}$ & 10 & 7 \\
\hline BOL SPACECRAFT MASS, $\mathrm{kg}$ & 14,000 & 7970 & 980 \\
\hline $\begin{array}{l}\text { TYPE OF ON-ORBIT } \\
\text { PROPULSION }\end{array}$ & $\begin{array}{l}\text { MONOPROPELLANT } \\
\text { HYDRAZINE }\end{array}$ & $\begin{array}{l}\text { HYDRAZINE } \\
\text { RESISTOJET }\end{array}$ & $\begin{array}{l}\text { HYDRAZINE } \\
\text { RESISTOJET }\end{array}$ \\
\hline REFERENCE & 4 & 8, THIS PAPER & 7,10 \\
\hline
\end{tabular}

- 75 year propulsion design IIfe

FIGURE 1. - BEGINNING OF LIFE (BOL) ON-ORBIT PROPULSION MASS FRACTIONS FOR LEO AND GEO SPACECRAFT 


$\begin{array}{cccc}\text { Mo Mandrel } & \text { CVDlr Over } & \text { CVD Re Over } & \text { Removr Mo } \\ \text { Mo Mandrel } & \text { It } & \text { Mandrel }\end{array}$
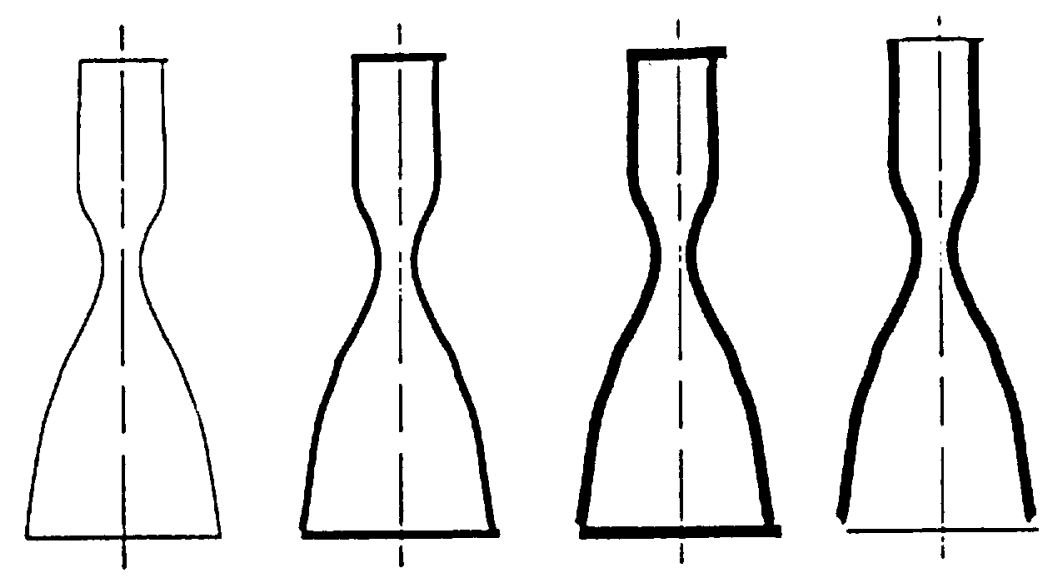

FIGURE 2. - BASIC INSIDE-OUT FABRICATION SEOUENCE FOR BIPROPELLANT THRUST CHAMBERS (ref. 25)

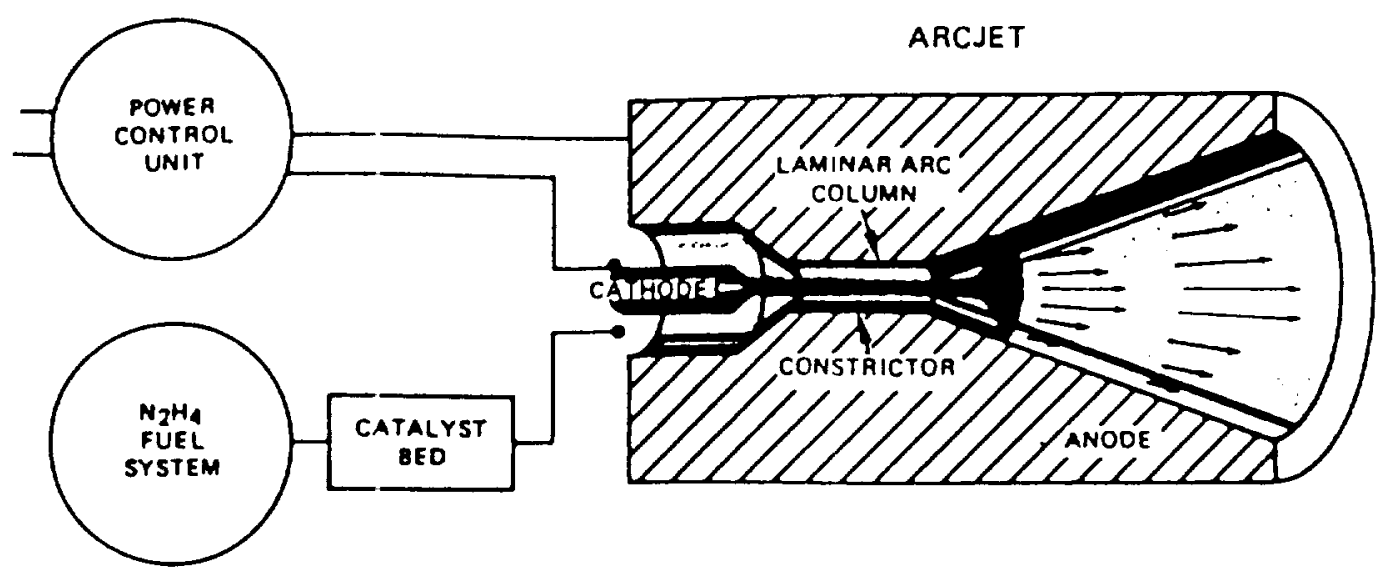

FIGURE 3. - 1.4 kW HYDRAZINE ARCJET (rof. 26) 


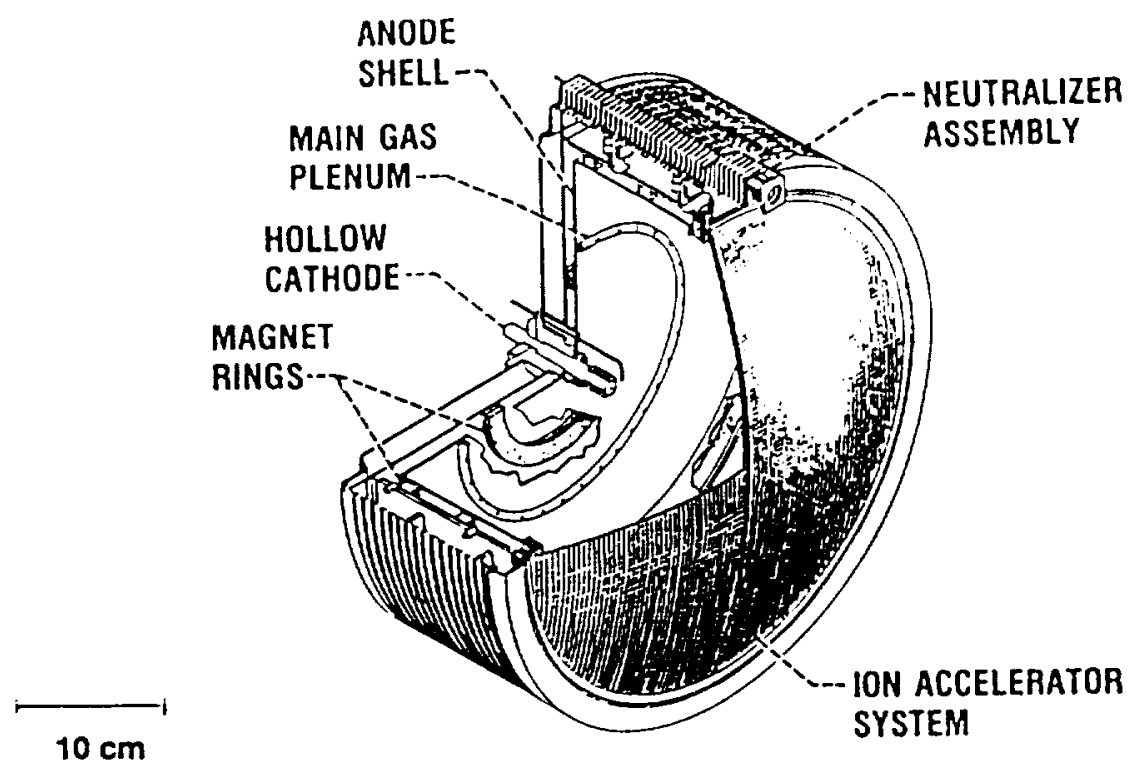

FIGURE 4. - XENON ION THRUSTER

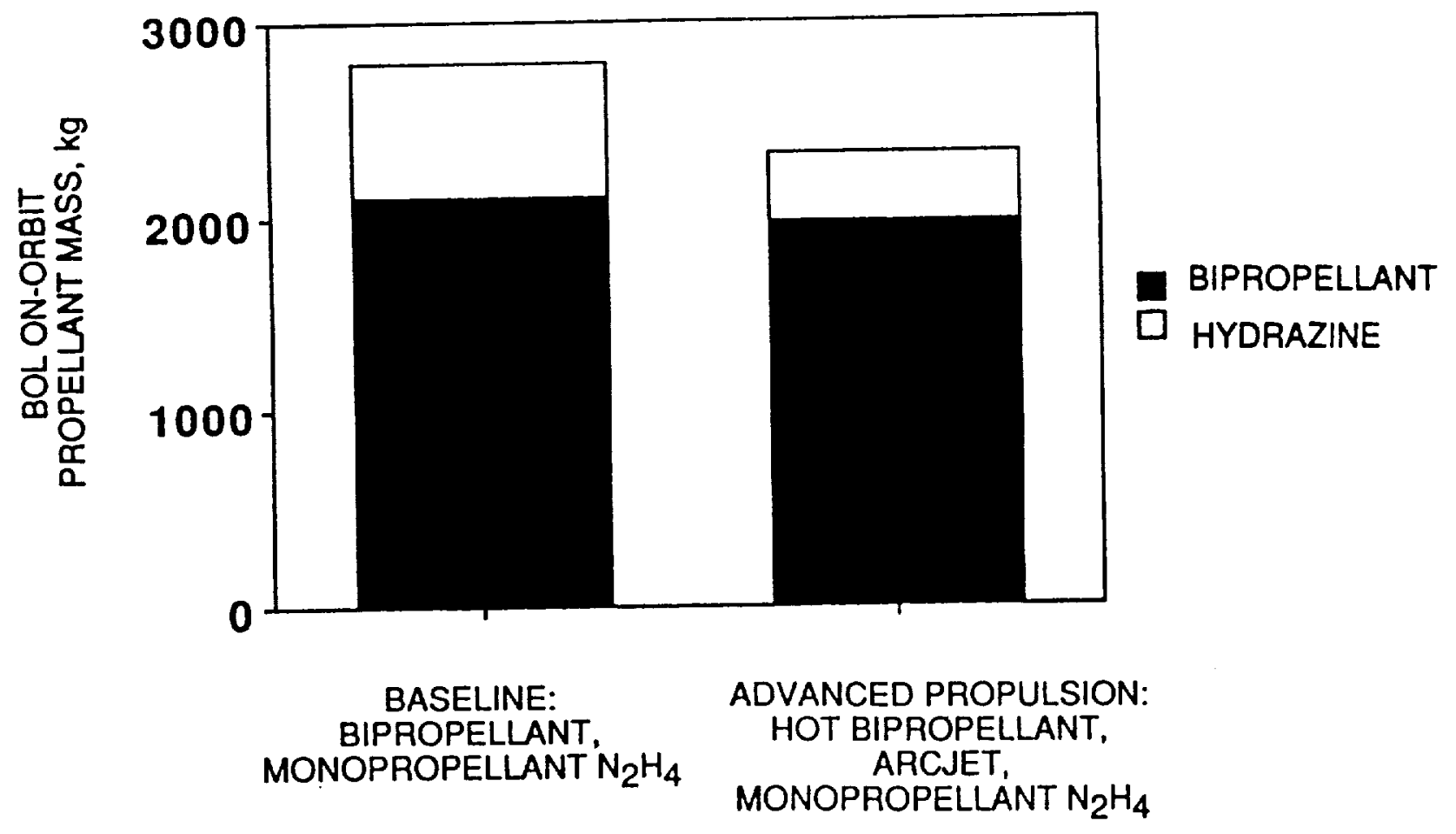

MASS SAVINGS OVER BASELINE EOS USING HOT BIPROPELLANTS AND ARCJETS: $398 \mathrm{~kg}$ *

- ADDED ARCJET SYSTEM: $+96 \mathrm{~kg}$ : REDUCED $\mathrm{N}_{2} \mathrm{H}_{4}$ TANKAGE: $-35 \mathrm{~kg}$

FIGURE 5. - PROPELLANT BUDGETS FOR EOS-CLASS PLATFORMS 


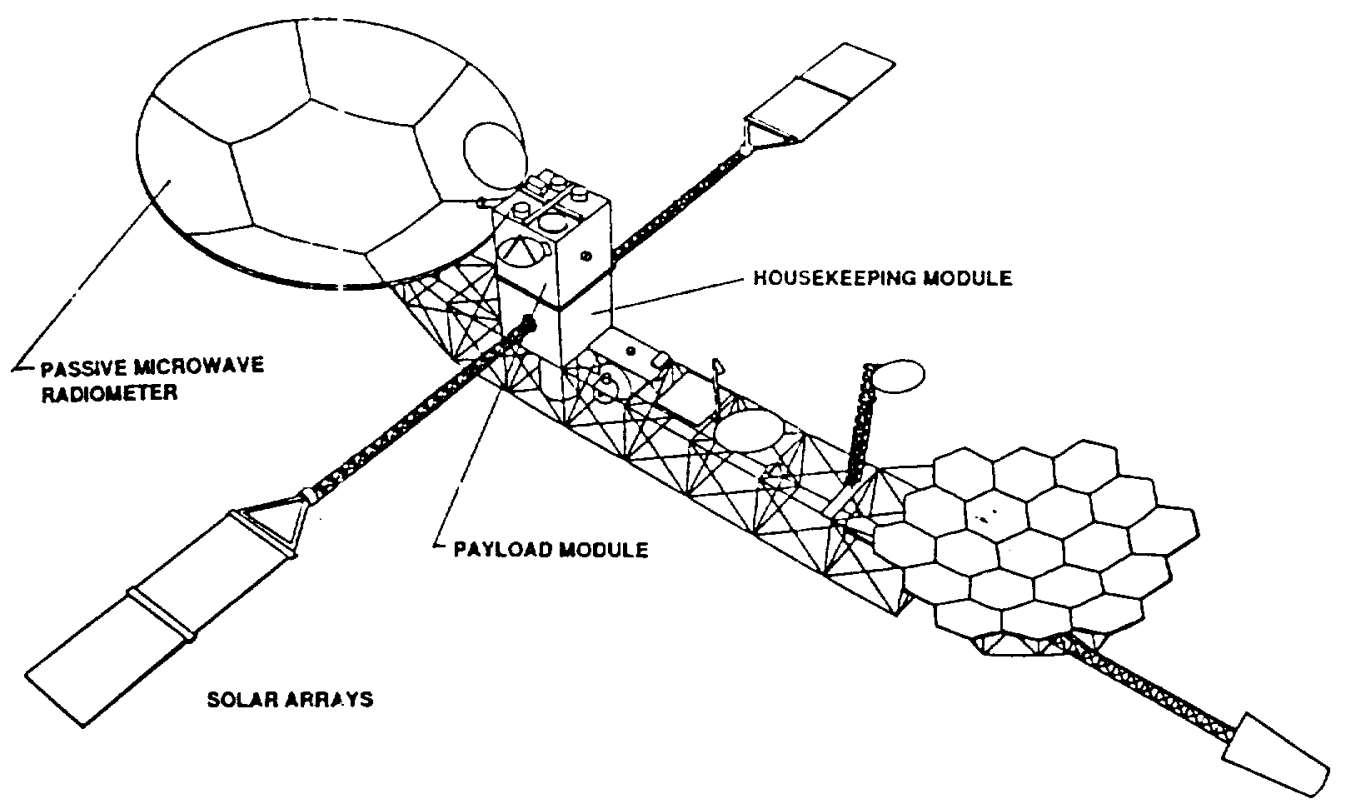

FIGURE 6. - GEOSTATIONARY PLATFORM CONCEPT

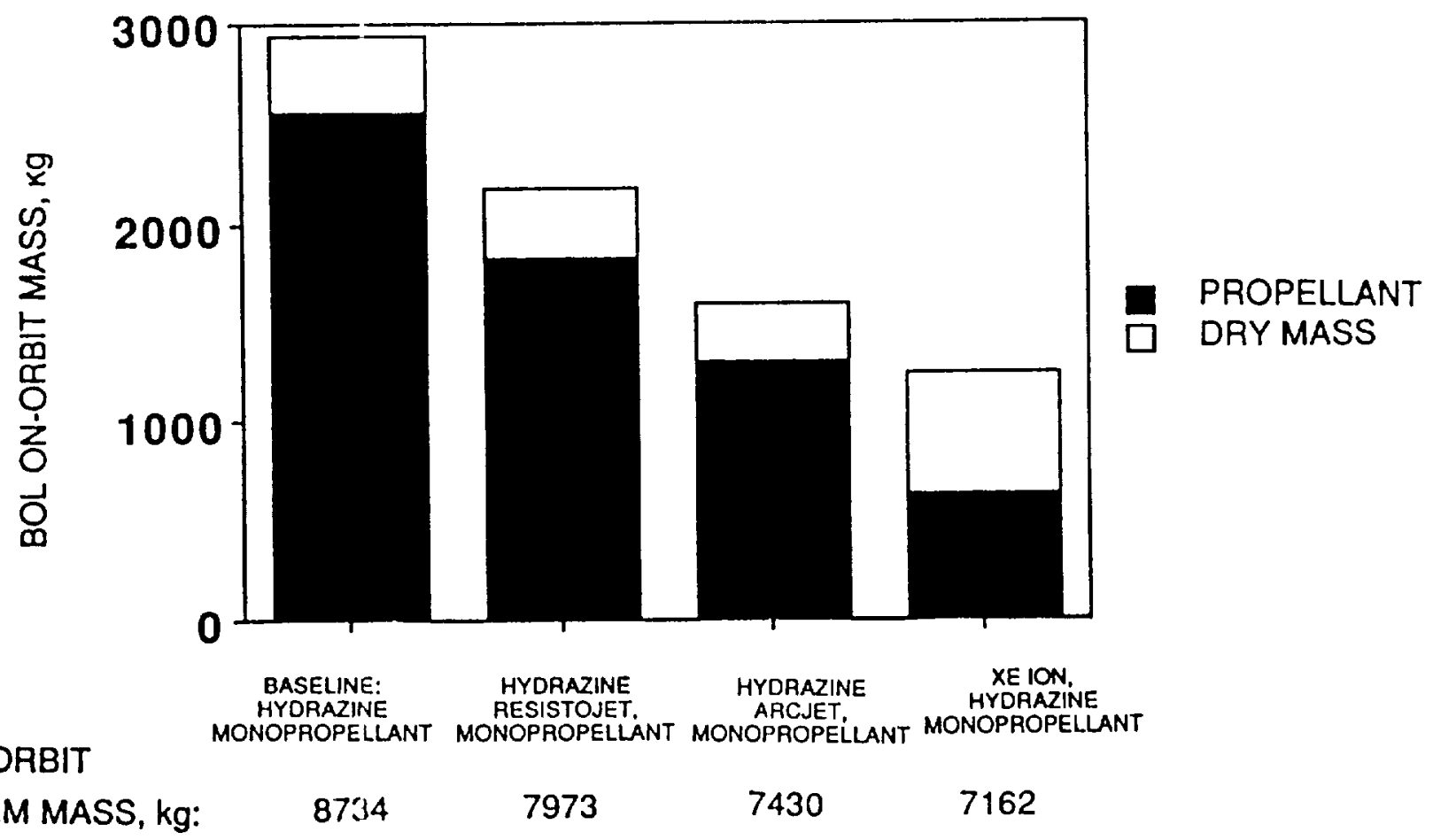




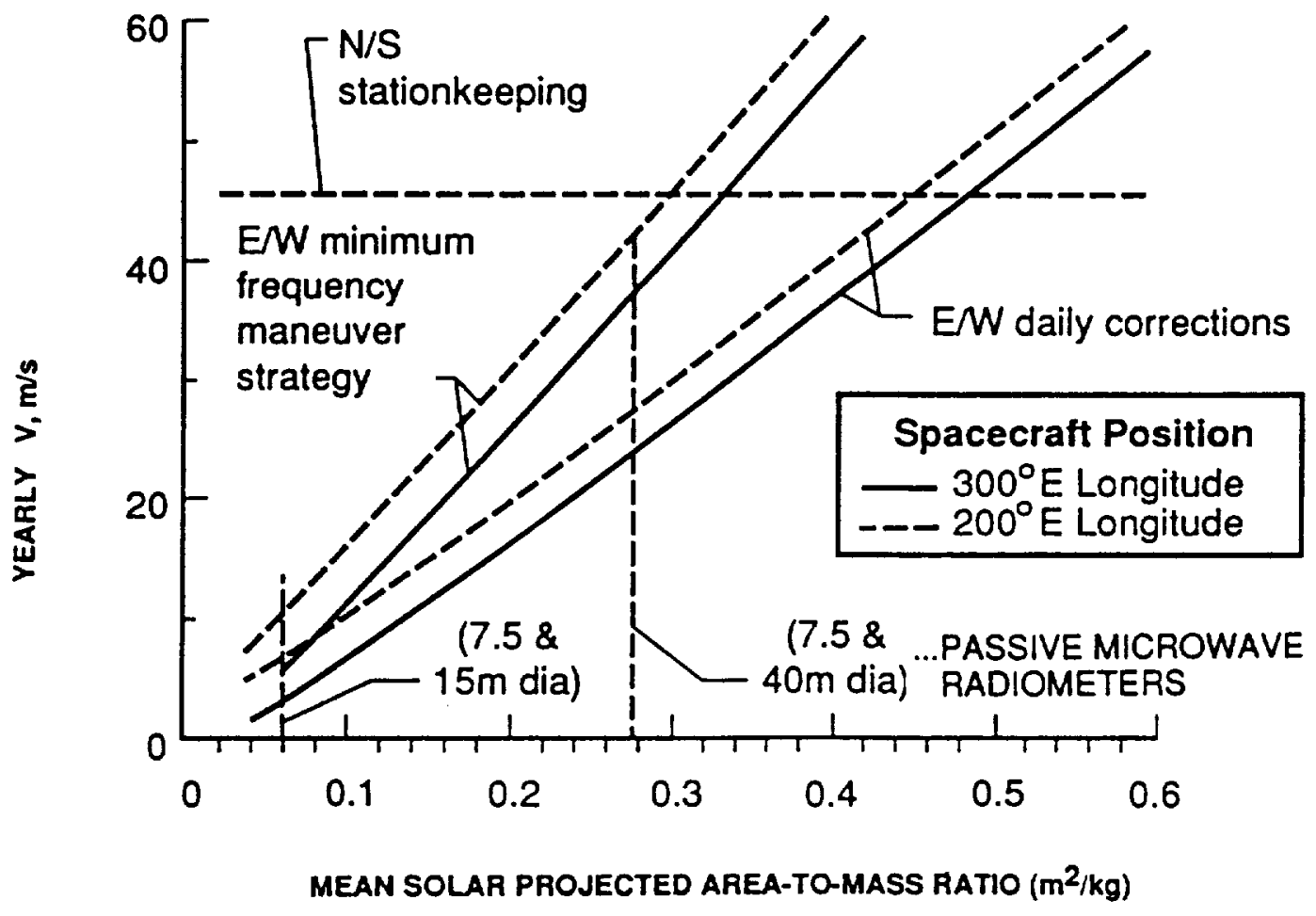

FIGURE 8. - STATIONKEEPING TRENDS: LONGITUDE VARIATION AND CORRECTION FREQUENCY 


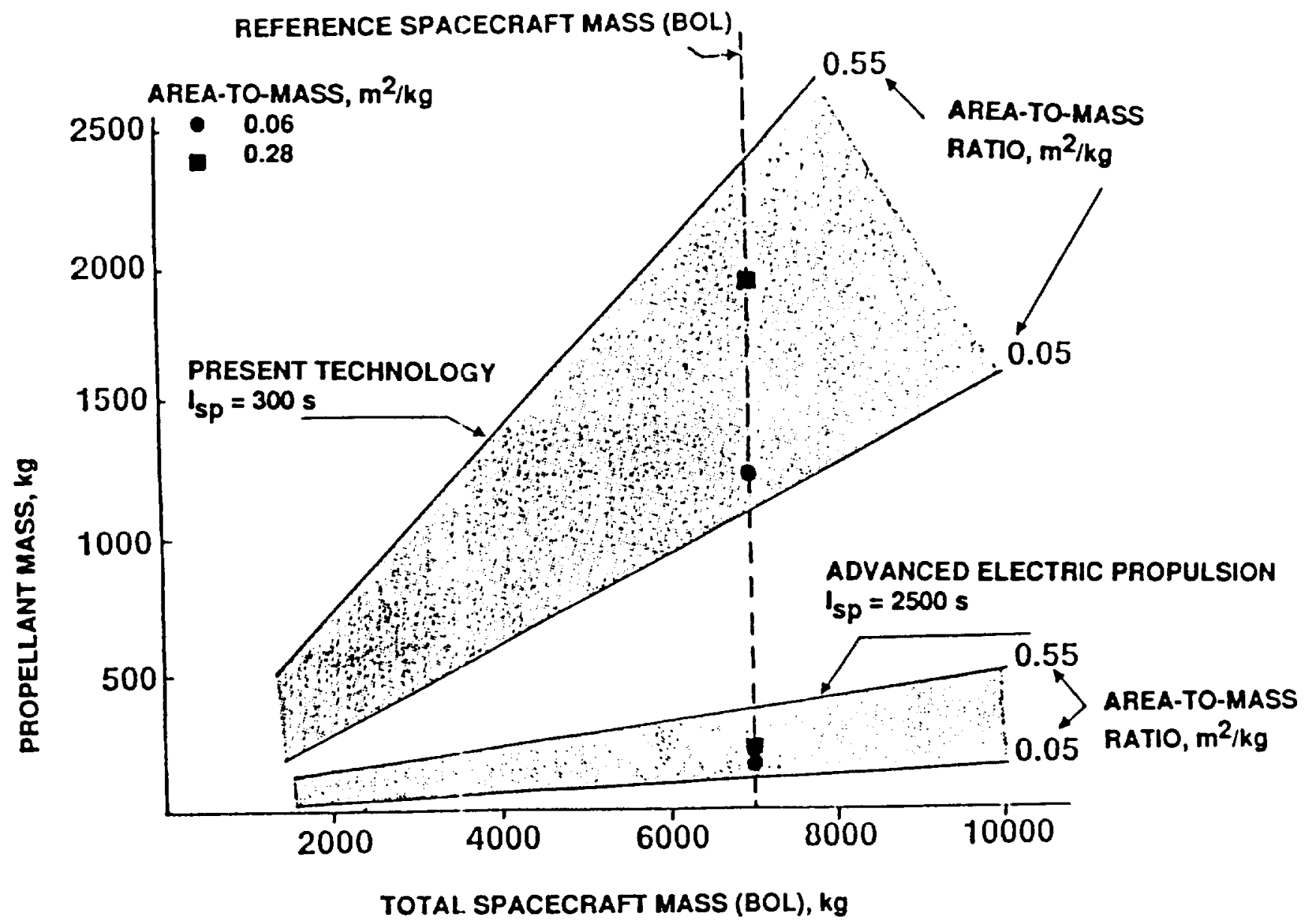

FIGURE 9. - COMPARISONS OF STATIONKEEPING PROPELLANT REQUIREMENTS FOR 10 YEAR LIFE IN GEO (ref. 8) 


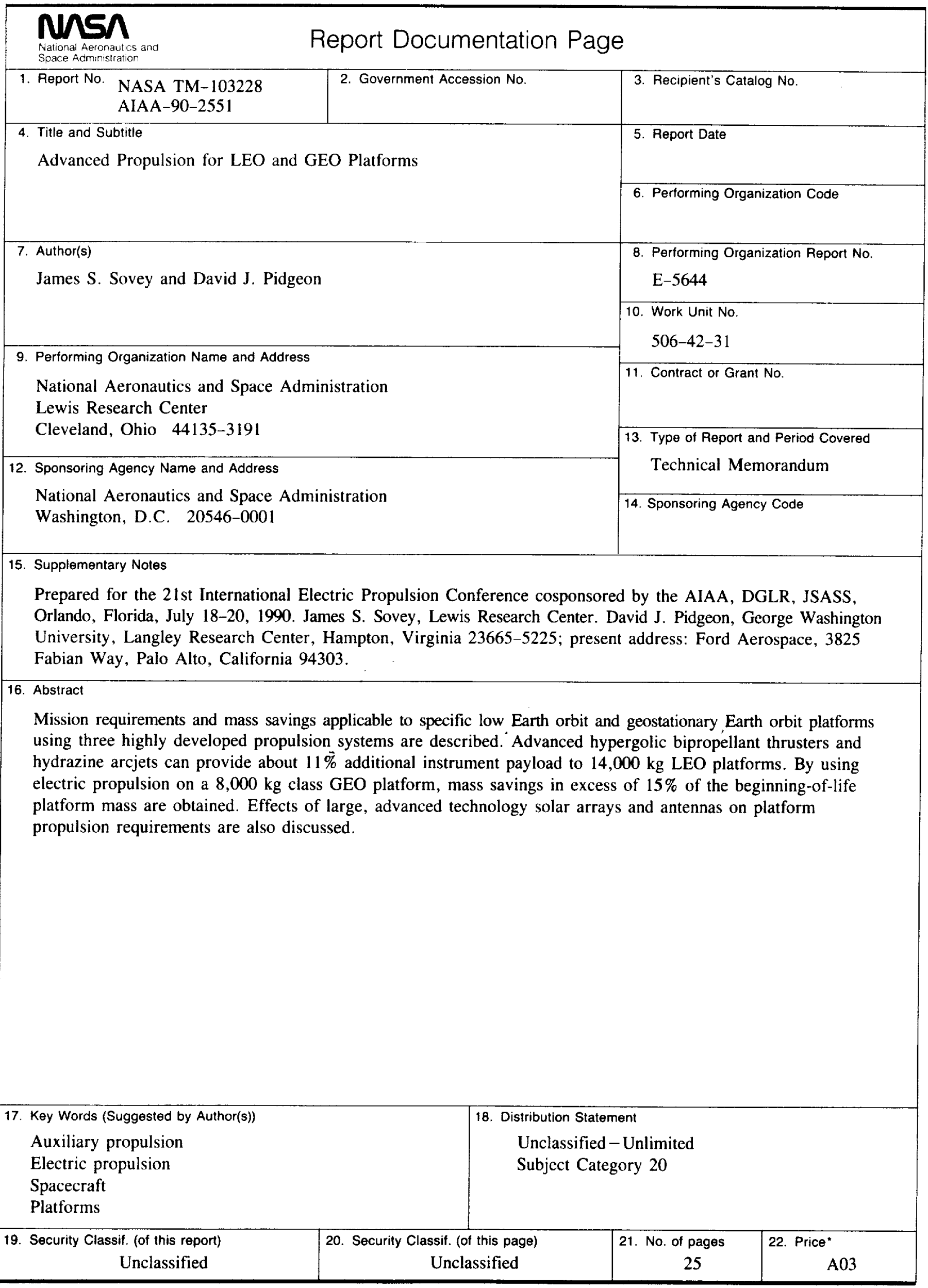

